\title{
1688 and all that: property rights, the Glorious Revolution and the rise of British capitalism
}

\author{
GEOFFREY M. HODGSON* \\ Hertfordshire Business School, University of Hertfordshire, Hatfield, Hertfordshire AL10 9AB, UK
}

\begin{abstract}
In a seminal 1989 article, Douglass North and Barry Weingast argued that by making the monarch more answerable to Parliament, the Glorious Revolution of 1688 helped to secure property rights in England and stimulate the rise of capitalism. Similarly, Daron Acemoglu, Simon Johnson, and James Robinson later wrote that in the English Middle Ages there was a 'lack of property rights for landowners, merchants and proto-industrialists' and the 'strengthening' of property rights in the late 17 th century 'spurred a process of financial and commercial expansion'. There are several problems with these arguments. Property rights in England were relatively secure from the 13th century. A major developmental problem was not the security of rights but their feudal nature, including widespread 'entails' and 'strict settlements'. 1688 had no obvious direct effect on property rights. Given these criticisms, what changes promoted the rise of capitalism? A more plausible answer is found by addressing the post-1688 Financial and Administrative Revolutions, which were pressured by the enhanced needs of war and Britain's expanding global role. Guided by a more powerful Parliament, this new financial system stimulated reforms to landed property rights, the growth of collateralizable property and saleable debt, and thus enabled the Industrial Revolution.
\end{abstract}

\section{Introduction}

A key problem for economic historians is to explain the innovations, rises in productivity and increases in the average standard of living that became evident in Great Britain by the 19 th century and spread to other countries in the world. ${ }^{1}$ Sometime after 1700, gross domestic product (GDP) per capita began to take off in Europe and accelerated further upwards. Western European GDP per capita

\footnotetext{
*Email: g.m.hodgson@herts.ac.uk

1 This paper extends some arguments in Hodgson (2015a). The author wish to thank Benito Arruñada, Michael Bordo, David Donald, Goncalo Fonseca, Anne Murphy, Sheilagh Ogilvie, Mehrdad Vahabi, two anonymous referees and participants at presentations (at the World Interdisciplinary Network for Institutional Research Symposium on Property Rights in Bristol, UK, at the Chinese University of Hong Kong in April 2016 and at the First International Conference on Cliometrics and Complexity in Lyon, France in June 2016), for very helpful comments and suggestions.
} 
was about 20 times greater in 2003 than it was in 1700 . World GDP per capita in 2003 was about 11 times greater than it was in 1700 (Maddison, 2007).

What enabled this unprecedented rise in production and innovation? This question was a major concern of the late Douglass C. North. Regarding Britain, North and Weingast (1989) stressed the importance of institutional changes following the Glorious Revolution of 1688. They claimed that it increased the security of property rights. Their argument has been followed by several others. But North's account has been subject to criticism. In particular, as several historians have pointed out, 1688 did not lead to major changes in property rights. It did mean a change in the de facto balance of power between the monarch and Parliament, but this was not a result of any major de jure legislation in the political settlement of $1689 .^{2}$

Rather than changes in the security of property rights, the alternative account here underlines how 1688 ruptured England's preceding international alliances and thrust the country into a series of wide-ranging wars against France and Spain, climaxing in the global Seven Years' War of 1755-1763. These wars prompted the Financial and Administrative Revolutions, which rested on the 1689 accord between King and Parliament. The need to protect and maintain a growing trading empire pressured the British state to reform its finances, gather more taxes, and purchase industrial, agricultural, and service outputs destined for its army and navy. The development of the financial system created new incentives and later possibilities for the use of landed property as collateral to finance investments infrastructure and industry.

Section 2 outlines the arguments of North and others concerning the alleged impact of the Glorious Revolution on the security of property rights. As a number of historians have pointed out, this revolution was essentially protective and conservative, and it involved few major legal changes.

Section 3 considers the evolution of property rights in England. Property rights, particularly in land, were relatively secure from the 13 th century. A major problem for capitalist development was the feudal nature of those rights. But the most rapid progress in the reform of landed property began in the $1750 \mathrm{~s}$, when much land became usable as collateral to finance loans for other projects. Similarly, a marked rise in patents - an important type of intellectual property did not occur until the 1760 s. Some property rights were made insecure, such as legislation to abolish heritable jurisdictions in the early 1700 s.

Section 4 examines the economic growth in the 17 th and 18 th centuries and concomitant changes in occupational patterns. Economic growth picked up around 1650 (long before 1688) but it remained steady until it began to accelerate

2 From 1603, England, Wales and Scotland were ruled by the same monarch. Hence, the invasion and accession of William of Orange in 1688 affected all three nations of Great Britain. But Scotland retained a partially separate legal system, even after the Act of Union of 1707 that created a single British parliament. 
after about 1760 (long after 1688). Evidence on the growth of social strata involved in industry and commerce shows that their percentage contribution to national income rose only slightly from 1688 to 1759 . Hence, there is no evidence of a strong shift of the balance of class power in favour of the bourgeoisie from 1650 to 1760 .

Section 5 looks at the Financial and Administrative Revolutions lasting from 1689 to the early decades of the 18 th century. In contrast to aforementioned indicators, immediately after 1689 , there is clear evidence of a growing state administration, increased taxation, and major developments in financial institutions. These changes were pressured by the growing needs of defence and war. In turn, these Financial and Administrative Revolutions extended the foundation for a capitalist system based on collateralizable property, negotiable debt, global trade, and state power.

Section 6 summarizes the argument - with its different chain of events connecting 1688 and the Industrial Revolution - and concludes the paper.

\section{1688 , the balance of power and property rights}

North and Weingast (1989: 803) argued that the development of Britain's modern economy depended on 'secure property rights' and the 'elimination of confiscatory government'. The Glorious Revolution was allegedly crucial in this process, including the constitutional settlement of 1689 between the Crown and Parliament, where the Declaration of Right made the king subject to Parliament on matters of legislation and taxation.

Hence, 'reducing the arbitrary powers of the Crown resulted not only in more secure economic liberties and property rights, but in political liberties and rights as well' (North and Weingast, 1989: 816). Accordingly, 'the credible commitment by the government to honour its financial agreements was part of a larger commitment to secure private rights' (North and Weingast, 1989: 824).

North and Weingast (1989: 825-828) pointed to a number of subsequent changes in the financial system, including the formation of the Bank of England in 1694, reductions in interest rates, rising trade in stocks and in securities, and the growth and development of banks. They cited these financial developments as the major confirmation of their claim that the settlement of 1689 helped to secure property rights and laid the foundations of 18 th-century economic growth.

Similarly, Acemoglu et al. (2005a: 393) suggested that in the English Middle Ages there was a 'lack of property rights for landowners, merchants and protoindustrialists' and that their 'development' first occurred in the late 17th century, when 'strengthening the property rights of both land and capital owners ... spurred a process of financial and commercial expansion'. They highlighted the 
settlement of 1689 , which limited the power of the monarch and facilitated 'the development of property rights. ${ }^{3}$

But crucial elements in this argument have been criticised by historians. Leading scholars have played down the extent of the constitutional settlement of 1689 by stressing its 'conservative' nature: it was aimed at the restoration of established rights, it salvaged previous constitutional arrangements after the turmoil of the Civil War and the Stuarts, and it was 'defensive' rather than innovative (Jones, 1992; Morrill, 1992; Nenner, 1997; Ogilvie and Carus, 2014; Pincus, 2009; Scott, 1991; Trevor-Roper, 1992; Western, 1972 ).

The settlement of 1689 ostensibly reinforced the de facto power of Parliament against the monarchy, but there was little rewriting of the rules. Although Parliament met more regularly after the Glorious Revolution, the Declaration of Right of 1689 was vague on this matter, and other legislation calling for frequent parliaments had been passed as early as the 14th century (Pincus and Robinson, 2014: 197). 'There was also no new legislation enjoining the supremacy of the common law' after the Glorious Revolution (Pincus and Robinson, 2014: 198). Pincus and Robinson (2014: 198) argued that legislation immediately following the Glorious Revolution was hardly innovative, and was preceded in 1624, 1644 , and 1677 by other legislation attempting parliamentary oversight of state finances. Pincus and Robinson (2014: 201) summed up their critique: 'While North and Weingast were right to insist on a radical change in English political behaviour after $1688 \ldots$ the mechanisms they have highlighted cannot have been the cause. ... The causes of England's revolutionary transformation must be sought elsewhere'.

Nevertheless, while the constitutional effects of 1689 may have been exaggerated by North and Weingast, there were important new controls by Parliament over sovereign powers and revenues. Generally, Parliament placed sovereign promises under its control (Cox, 2012, 2016). Financial legislation in 1690 ended most lifetime grants for the King and replaced them by timelimited stipends (Roberts, 1977). The Mutiny Act of 1689 made Parliament indispensable for the monarch in times of war. Overall, the King became more dependent on Parliament than before.

But it has not been shown that this constitutional shift affected property rights. This remains a major problem with the North-Weingast thesis. Some scholars have pointed out that property rights were already relatively secure before 1688 , by 1600 or even earlier (Angeles, 2011; Clark, 1996, 2007; McCloskey, 2010; Ogilvie and Carus, 2014; Sussman and Yafeh, 2006). Other historians have suggested that the effects of 1688-1689 on the security of public and private financial activity were neither obvious nor immediate. Murphy (2009: 5) pointed out that 'the financial promises of the post-Glorious Revolution were no more credible than those of previous Stuart monarchs'. Murphy (2013) also argued

3 For similar arguments, see Olson (1993, 2000) and Acemoglu and Robinson (2012). 
that post- 1689 'credible commitment' to protect property was demanded from below by financial investors, and it was not offered from above.

Explicitly against North and others, Hoppit (2011) and Ogilvie and Carus (2014) argued that property was no more secure after the Glorious Revolution: the very fact that Parliament met more often posed greater legislative risks to property. Hoppit (2011: 108) noted forms of property that became more insecure after 1688: 'Heritable jurisdictions were courts and offices granted by the Crown to individuals and effectively owned as freeholds to be passed on by inheritance, gift or sale as they chose'. Although jealously guarded as sources of revenue and prestige, heritable jurisdictions began to be phased out in the early 18 th century, leaving such offices to be filled by salaried appointments. The 1833 British abolition of property in slaves is a dramatic later example of property made insecure. ${ }^{4}$

Whatever the chain of causation, Britain's industrial development gathered pace much later. As Clark (1996: 588) put it: 'Institutionalists were stretching a point when forging the link between the institutional changes of 1688 and the Industrial Revolution beginning in 1760'. Allen (2009) questioned similarly: if the outcome of the Glorious Revolution was so crucial for property and business, then why did England have to wait the major part of a century for the surges in innovation and productivity in the Industrial Revolution? ${ }^{5}$

This controversy concerns both facts and analysis. Economic history depends on the use and interpretation of empirical data. But the questions asked by economic historians, and the types and interpretations of the data employed, depend crucial on judgements informed by economic and social theory. Much of the discussion concerning the economic consequences of the Glorious Revolution has been guided by an unsatisfactory notion of property rights and views of monetary and financial institutions that underplay their conjunction with collateralizable property and debt. The aim here is to illustrate the plausibility of a new argument, based on an enriched conception of property, while stressing underestimated aspects of finance. Once property and finance are better understood, a new solution to the puzzle concerning 1688 appears.

This paper does not challenge the importance of property rights in economic development, but focuses on their deeper legal substance and their evolving, multi-faceted nature. Because, surprisingly, the very notion of 'property rights' is undeveloped in much institutional economics, these important nuances and changes have been often overlooked in debates about the role of property rights in

4 British slave-owners, however, did receive compensation. Much of this capital was invested in the railway boom of the 1840 s.

5 These apparent deficiencies in the timing and substance of institutional explanations led Deirdre McCloskey $(2010,2016)$ to emphasize instead the role of ideas in Britain's take-off from the late eighteenth century. 
development (Cole, 2015; Cole and Grossman, 2002; De Soto, 2000; Heinsohn and Steiger, 2013, Hodgson, 2014, 2015a, 2015b, 2015c, Steiger 2008). ${ }^{6}$

In England, property rights (of a kind) existed and were relatively secure long before 1688 . Slowly the nature of those rights changed, enlarging possibilities for the use of land and other property as collateral to finance business ventures. This does not necessarily diminish the politico-economic importance of the Glorious Revolution, but it shifts the analytical emphasis. It establishes a stronger connection between the growing use of property as collateral and the development of financial institutions, particularly in the Financial Revolution of the early 1700s. Developments concerning property and finance are intimately conjoined. North and Weingast claimed that 1688 secured property rights led to the rise of finance; instead, it is stressed here that the rise of finance stimulated the greater use of property as collateral for borrowing and financing investment.

The establishment of the Bank of England in 1694 was prompted by the need to finance a major war that broke out in 1688, as a result of the Glorious Revolution and England's new foreign alliances. It was part of a chain of institutional events that led to the development of a modern financial system in Britain, with the crucial role of the state in gathering taxes, issuing bonds and loans, buttressing private banks, and acting as lender of last resort. Hence, it is important to understand the nature of modern financial systems (Carruthers, 1996; Hodgson, 2015a; Ingham, 2004, 2008; Keynes, 1930; Mitchell Inness, 1914; Moore, 1988; Wray, 2012).

Unfortunately, there is a paucity of processed data in the period concerning the extent to which property was used as collateral, the scale of loans and investment, and the growth in the market for debt. By contrast, key legislative steps concerning changes to property rights and finance are known. Nevertheless, the central argument here must be considered as a hypothesis, awaiting further detailed empirical confirmation.

\section{Bad timing: the evolution of property rights in England}

Were property rights insecure in medieval times? European countries were not uniform in this regard. We should not overlook the relatively advanced legal developments in England, compared to most other European countries.

Acemoglu et al. (2005a: 394) cited Veitch (1986) to assert that there were 'numerous financial defaults by medieval kings'. Veitch (1986: 31) himself wrote: 'Property confiscation and debt repudiation were common in medieval Europe'.

6 If (economic) 'property rights' are defined in terms of possession or control (Alchian, 1965; Barzel, 1989), then evidence of their distinctive importance in promoting economic development is more elusive. But it would be mistaken to follow Angeles (2011) and others and eschew the general importance of 'property rights' in this context. Instead, 'property rights' need to be much better understood. This basic injunction flows from the approach dubbed as 'legal institutionalism' (Deakin et al., 2016; Hodgson, 2015a). 
From this, Acemoglu and his colleagues infer that such insecurity was rife in England as well. But Veitch gave only four examples of property confiscation or debt default applying to medieval England. In particular, he noted that Edward I expelled the Jews and confiscated their property, and that Edward I, Edward II, and Edward III all defaulted on Italian debts. These events occurred from 1290 to 1340 and targeted very few English property owners.

There were several confiscations after the medieval period. Henry VIII seized monastic lands in 1536-1541; in 1638 Charles I appropriated $£ 200,000$ in coin and bullion from the London Mint to finance a war against Scotland; and Charles II defaulted on his debts in 1672. As North and Weingast (1989: 819-820) pointed out, from 1604 to 1628, James I and Charles I extracted a number of forced loans from English lenders. Of course, if a landowner committed treason or supported the wrong side in a civil war, then he would likely forfeit his lands. Otherwise, English kings sometimes seized property or defaulted on contracts, but compared with much of Continental Europe, these were less frequent events.

In the 12th and 13th centuries, new legal systems were developed in England, and to some extent in other parts of Northern Europe, under the influence of the new canon law of the church, and the discovery of Justinian Roman law (Berman, 1983, 2003). Consequently, with its long-established system of property, contract, and criminal law, property rights for the wealthy were quite well entrenched in England, at least since the 13th century.

Of course, justice was much less accessible by the poor and the legal system was often subject to corruption and inefficiencies. The many surviving letters of the Paston family - who were raising landed gentry in Norfolk in the 15th century - illustrate the tedious complications and corruptions of laws concerning the ownership of land (Castor, 2006). But the main problem for them was not the threat of confiscation by a powerful monarch.

The standard focus by North and others on 'secure property rights' points to events that are too early and too late. Property rights in England were relatively secure for the minority by the 13th century, but legal rights for the majority were insecure even during the Industrial Revolution. In addition, this standard view fails to distinguish between multiple types of property right, including the differences between rights to use, rights to sell, inheritance rights, and rights to use property as collateral (Honoré, 1961).

Before the Industrial Revolution, by far the most important type of wealth was in land. A foremost obstacle to the development of commerce was not the insecurity of property rights, but the feudal nature of landed rights. Long after the decline of classical feudalism in England, enduring and well-defined rights often carried feudal obligations that limited the use of this wealth for investment and constrained the growth of markets, finance, and capitalism.

While landholding had been subject to important legislation, including the 1660 abolition of military tenures by Charles II (which in most cases replaced the obligation of tenant farmers to military service by rental payments), 
land remained a major source and symbol of power for the families that owned it.

In particular, there were enduring restrictions on landed property, known as entails. Many entails enforced primogeniture, ensuring that a landed estate passed from one generation to another through the eldest son. This limitation on a right for the living owner of the estate became an enhanced right for his future heirs. But even when the courts limited the scope of entails in 1614, these were replaced by voluntary and widespread 'strict settlements' that had similar effects, and prevailed until the 19th century (Allen, 2012: 65; English and Saville, 1983; North et al., 2009: 89-89).

Entails and strict settlements 'restricted the uses to which land could be put. ... Holders could seldom sell, swap, or mortgage property under their control. Holders could not alter property, even if they considered the alterations to be an improvement, without risking legal suits ... [and] conducting transactions and enforcing contracts on settled land could be costly, uncertain, and insecure' (Bogart and Richardson, 2011: 245).

It required much ongoing legislation to remove entails and strict settlements. They stubbornly endured, largely because the wealthy elite endorsed them. Owners were disinclined to sell or mortgage buildings or land that had been in their family for generations. Loss of land meant loss of status, influence, titles, and privileges. ${ }^{7}$

Much land was set aside as commons, for the shared use of villagers. It has been estimated that at the beginning of the 18th century about one-quarter of arable land in England was held as commons, where villagers shared rights to the use of pastures, water sources, or woods (Bogart and Richardson, 2011: 247). This common land could not be sold or mortgaged.

These restrictions on the saleability of property were important not simply because they held back the development of English agriculture, which could release labour for growing industry once agricultural productivity increased. In addition, commons, entails and strict settlements greatly inhibited the use of land as collateral for loans, which could be invested in mercantile, industrial, and infrastructural ventures.

The potential role of property as collateral is neglected in much of 'the economics of property rights' (Alchian, 1965; Barzel, 1989), which often focuses on the matter of de facto control, rather than on the importance of de jure legal title, granted by a juridical authority (Arruñada, 2016; Cole and Grossman, 2002, Hodgson, 2015a, 2015b, 2015c). North (1981: 17, 1994: 361) himself

7 Feudal restrictions on landed property existed in pre-1789 France. But France was different from England in other crucial respects. There was a massive state bureaucracy, surmounted by a powerful King: lacking were adequate political checks and balances. Unlike England and the Netherlands in the eighteenth century, there 'was no developed capital market upon which the state could market its debt. Rather, France raised money through a complex and cumbersome system of tax farms, private bankers and venal offices' (Carruthers, 1996: 23). 
made it clear that 'the state specifies the property rights structure' and 'propertyrights dimensions are defined in legal terms' but he did not explore the key aspect of legal property as possible collateral.

Barriers to the commodification of land and its use as collateral did not disappear spontaneously or easily, despite the political convulsions of the 15 th, $16 \mathrm{th}$, and 17th centuries. They were defended by strong and enduring vested interests. It took numerous varied Acts of Parliament to remove them, lasting well into the 19th century.

Every enclosure of common lands meant the appointment of commissioners and surveyors, the holding of village meetings, and adjudication in cases of dispute. Enclosures in England date back to the 13th century, but these were countered by anti-enclosure acts in 1489 and 1516. Enclosures accelerated thereafter, sometimes provoking rural revolts. Some enclosures were imposed arbitrarily, some were agreed voluntarily and some were imposed by Acts of Parliament. We have reliable data for Acts of Parliament only. ${ }^{8}$

Estate acts undid strict settlements and statutory authority acts were used to develop infrastructure, including improvements to roads, rivers, and the construction of canals (and later railways). Estate, statutory authority, and enclosure acts all had a common theme: they relaxed constraints on the use of land and resources. Procedures for passing these acts were standardized in the early 18th century and operated with minor adjustments through the 19th century (Bogart and Richardson, 2011: 248).

Bogart and Richardson (2011: 249-250) collected parliamentary data on the numbers of estate, statutory authority, and enclosure acts from 1700 to 1830 . Figure 1 depicts the key trends. There was also a small spurt of such legislation between 1688 and 1700, which is omitted from the data, but this upturn was small compared to the post-1750 increases (Bogart, 2011; Pincus and Robinson, 2014: 203). The clear conclusion from these data is that legislative reform of landed property rights was sluggish from 1700 until about 1750 and then took off dramatically, with the strongest growth trends coming from enclosure and statutory authority acts. The all-important erosion of entails and strict settlements was a slow and steady process, lasting well into the 19th century.

Overall, the release of land for sale or collateralization, through the combined effects of estate and enclosure acts, was a process that extended well into the era of industrialization after 1760 . The removal of feudal elements in property law was a lengthy process, beginning before 1688 and continuing long afterwards.

Many of these changes were instigated by local interest groups. Others were instigated by Parliament itself. Many property owners or users received

8 It is unnecessary for the purposes of this argument to assess whether enclosures improved agricultural productivity or not. This has been a matter of some empirical investigation and dispute (Turner, 1986). Ostrom (1990) showed that collective arrangements remained viable in many diverse circumstances. The more important point here is that enclosures made land saleable and usable as collateral. 
Figure 1. Parliamentary acts reorganizing landed property rights, 1700-1830.

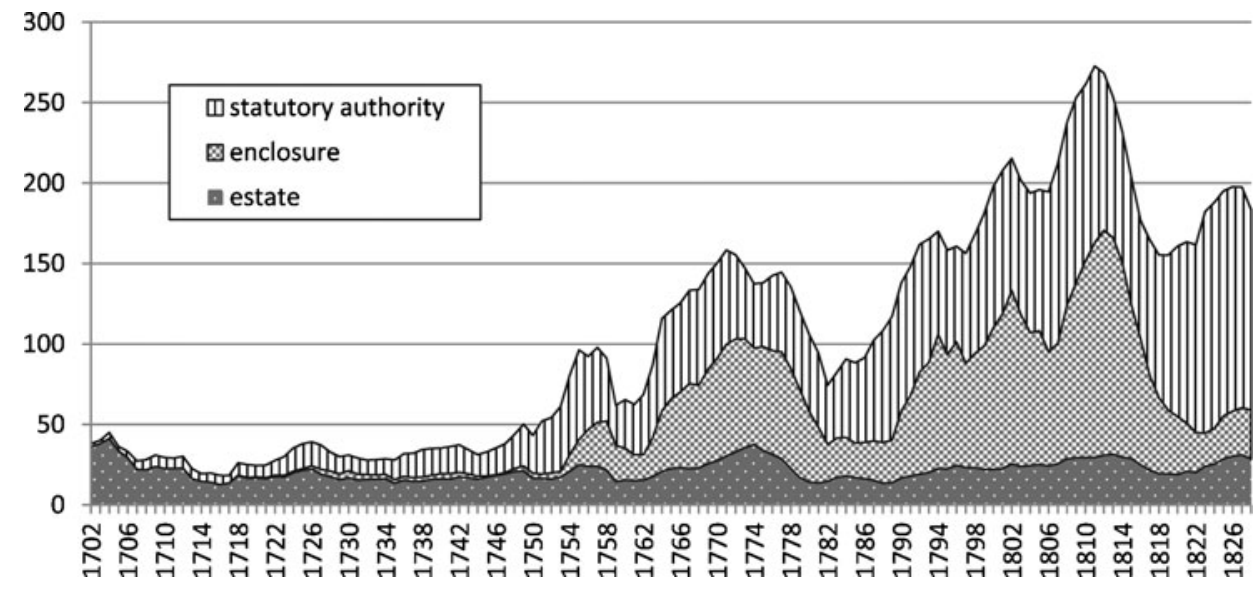

Source: Five-year moving averages, in a vertically cumulative presentation, using annual data from Bogart and Richardson (2011: 250).

compensation. Overall, the effects were enormous. As Hoppit (2011: 100) reported, legislation on landed property, 'between 1750 and 1830, not only redistributed some property rights, but redefined or clarified the meaning of others in ways which many villagers disputed. Over 5,200 acts were passed, involving up to 6.8 million acres, some 21 per cent of England's surface area'.

Bogart and Richardson (2011: 270) argued that the 1689 Declaration of Right and subsequent more regular meetings of Parliament 'encouraged the expansion of legislative activity'. But the dismantling of entails and strict settlements, and the enclosures of common lands, met significant enduring resistance from higher and lower strata of society. The 1689 settlement may have enabled such legislation, but it does not explain why people became incentivized to promote it, and how conservative vested interests in the status quo were overcome. ${ }^{9}$

Patents are an important form of intellectual property and loose indicators of the pace of industrial innovation. Notably, patenting was very expensive, and numerous innovations were not patented. Patents are highly imperfect indicators of overall innovation. Nevertheless, unlike unregistered innovations, patents are a saleable and collateralizable property, and are important to consider, at least for that reason.

9 Pincus and Robinson (2014: 203) and Bogart (2011) pointed out that the immediate effects of post-1688 statutory authority acts led to surges in investment in road and river improvements from about 1690-1730. But Bogart's (2005) own data show clearly that this early upturn of activity was minor compared with the much larger expenditures on infrastructural developments after 1730. Expenditure on turnpike roads alone tripled from 1730 to 1760 , and grew impressively thereafter. Overall, while there were some infrastructural developments from 1690 to 1730 , much more remarkable progress was made in later years. 
Patents gradually evolved from 17 th-century instruments of royal patronage into the intellectual property of the inventors and manufacturers of the Industrial Revolution (MacLeod, 2002). The British patent system was systematized and became more accessible during the reign of Queen Anne (1702-1714). But the annual number of patents awarded remained low, until a marked rise in about 1760, with an acceleration thereafter (Sullivan, 1989; Dutton, 1984).

In summary, the North-inspired 'secure property rights' argument has four major flaws - historical, analytical, motivational, and distributional. Historically, property rights were mostly secure in England for the landed nobility from the 13th century, with relatively few debt defaults or confiscations of wealth by medieval monarchs. Furthermore, particular kinds of property right were made less secure by increasing parliamentary powers, including the enforced removal of entails.

Analytically, to enable the rise of capitalism, a major problem with older property rights was not their insecurity, but their entangled, feudal nature. In particular, the property rights of an heir to his father's estate prevented the sale of such property or its use as collateral for loans. In a sense, the problem was not that there were too few property rights, but too many. ${ }^{10}$

Motivationally, it is overlooked that strong vested interests protected the feudal nature of landed property rights. The nobility enjoyed huge wealth and power. Much of the nobility and landed gentry resisted the reforms to landed property rights including the removal of entails and strict settlements. These vested interests were not immediately diminished by the events of $1688-$ 1689. Major institutional changes were required to provide incentives for the commercialization of land and to enhance a money-making culture, over and above matters of status based on landed property. These changes did not occur until sometime after 1689.

Distributionally, the full flowering of capitalism required the extension of real and enforceable legal rights, from a narrow elite to a much bigger slice of the population. Such extensions often compromised the rights of existing property owners, and were often resisted for that reason. Nineteenth-century examples of ending property rights for some, in favour of the rights of many others, included the abolition of slavery and the removal of the automatic right of a husband to the property of his wife upon marriage (Hoppit, 2011, Hodgson, 2015a: 120-122).

Some accounts concerning the role of 'secure property rights' suggest that, once these were in place, institutions would largely be ready to support investment and entrepreneurship. This is mistaken. At least in the English case, a major problem was to reform well-established and secure property rights, not

10 Thickets of property claims were the feudal version of the 'anti-commons' problem of multiple entangled rights in modern capitalism (Heller, 2008). 
to establish them. Furthermore, the evidence suggests that the more dramatic changes in the nature of property rights came after 1750 .

\section{Economic growth and the balance of class power}

The change in the balance of power between the sovereign and parliament, and the increased frequency of parliaments, may have increased possibilities for the development of commercial institutions; they do not explain the rise and empowerment of vested interests that could lobby for these changes and make them real. Crucial were the development of the bourgeois class, engaged in business and manufacturing, and a commercially-minded landed gentry, oriented more to trade and profit than to feudal power and status. ${ }^{11}$ It was in the interests of these groups to support financial, administrative, and property reforms, which helped expanding business and trade. When did these classes begin to exert greater economic weight and potential influence?

Acemoglu et al. (2005b) argued that economic development in Britain and elsewhere was partly stimulated by rising Atlantic Trade from the 16 th century. This strengthened the political power of the bourgeoisie and stimulated a cumulative process of institutional reform. Earlier arguments along similar lines are found in works by Cipolla (1965) and Braudel (1984). These analyses point to positive feedbacks and processes of cumulative causation, leading to rises in bourgeois power.

Britain's involvement in global trade increased hugely in the second half of the 17th century. Between 1640 and 1700, its exports roughly doubled. By 1688, Britain had the largest merchant marine fleet in Europe, which had increased from 2 million tonnes in 1660 to 3.4 million in 1686 (O'Gorman, 1997, ch. 1). The slave trade expanded massively. The numbers of slaves transported by British traders from Africa to the Caribbean and North America increased from 243,300 in $1676-1700$, to 380,900 in $1701-1725$, to 490,500 in $1726-1750$, and to 859,100 in 1751-1775 (Eltis, 2001: 43). But all these expansions began before 1688 .

Because of the Civil War and other disturbances, English GDP per capita grew slowly in the first half of the 17th century. But economic growth had picked up substantially after the end of the Civil War in 1649. Data calculated by Broadberry et al. (2015: 199) suggest that GDP per capita grew from 1650 to 1700 at an average rate of 0.74 per cent per annum. From 1700 to 1760 , the growth figure is slightly lower at 0.67 per cent. After 1760, GDP per capita growth rose: from 1760 to 1780 the rate was 0.85 per cent, from 1780 to 1801 it was 1.46 per cent, and from 1801 to 1830 it was 1.64 per cent per annum.

11 Marx (1976: 875-876) argued that the development of wage labour was the 'starting point' of capitalism. He saw this development as taking hold in the sixteenth century. In fact, wage labour was prominent in England by the fifteenth century (Hodgson, 2015a). 
Table 1. Landowners versus traders and manufacturers: percentages of families and national income from 1688 to 1803

\begin{tabular}{|c|c|c|c|c|}
\hline \multirow[b]{3}{*}{ Survey date } & \multicolumn{2}{|c|}{ Landowners } & \multicolumn{2}{|c|}{ Traders and manufacturers } \\
\hline & \multicolumn{2}{|c|}{ Lords, esquires, and gentlemen } & \multicolumn{2}{|c|}{$\begin{array}{l}\text { Merchants, tradesmen, } \\
\text { manufacturers, builders, and miners }\end{array}$} \\
\hline & $\begin{array}{l}\text { Per cent of } \\
\text { families }\end{array}$ & $\begin{array}{l}\text { Per cent of } \\
\text { national income }\end{array}$ & $\begin{array}{l}\text { Per cent of } \\
\text { families }\end{array}$ & $\begin{array}{l}\text { Per cent of } \\
\text { national income }\end{array}$ \\
\hline 1688 & 1.4 & 16.2 & 27.7 & 37.6 \\
\hline 1759 & 1.2 & 17.6 & 36.8 & 38.5 \\
\hline 1801-1803 & 1.2 & 13.9 & 34.0 & 45.5 \\
\hline
\end{tabular}

Source: Lindert and Williamson's (1982: 393-3401) data for England and Wales

These data suggest that the most dramatic acceleration of growth began around 1760 , and not immediately after $1688 .^{12}$

Consider the rising strata of financiers, merchants, manufacturers, and commercial farmers. Giving evidence of changes in the relative importance of different occupations and social classes in the 17th and 18th centuries, Lindert and Williamson (1982: 393-401) reported and adjusted data from three pioneering social surveys, by Gregory King in 1688, Joseph Massie in 1759, and Patrick Colquhoun in 1801-1803.

Table 1 presents the proportion of families in two important groups of socioeconomic classes, and the contributions to national income by each of these groups, from 1688 to 1803 . The landowning group consisted of the lords, nobility, and gentry. This evidence suggests that their social presence and proportion of income did not change greatly in this period, except for a small decline in their proportion of income from 1759 to 1803 . We may conclude that the politico-economic influence of these landowning social classes remained high, long after $1688 .^{13}$

The second group reported here consisted of those classes engaged in mercantile, trading, manufacturing, building, and mining activity. It includes employers, employees, and self-employed engaged in these activities. It indicates the social weight and revenues of the commercial and industrial sectors.

According to these data, by 1688 over a quarter of families were occupied in commerce and industry and they generated over a third of national income. Table 1 shows that these developing social strata were on the rise long before 1688. The bourgeoisie was already of economic significance in 1688, albeit

12 Other data series for this period paint slightly different pictures, but concur in finding no discernible acceleration of growth after 1689. Ogilvie and Carus (2014) review the evidence on growth in Britain in the seventeenth and eighteenth centuries.

13 Before the Reform Act of 1832, the franchise for parliamentary elections was confined to male property owners only - estimated at about 400,000 men (about 10 per cent of the adult male population) in England and Wales (Phillips and Wetherell, 1995: 413). 
with less power and influence than the nobility. Subsequently, from 1688 to 1759 , the number of families involved in commerce and industry increased, but their percentage contribution to the national income swelled only slightly. Their contribution to national income increased more substantially after $1759 .{ }^{14}$

These social surveys show that while the bourgeoisie were already of economic significance in 1688, their economic presence did not increase greatly for the next 70 years, but they became more important thereafter. Again the data point to decisive economic changes occurring in the 1750 s or after.

If the security of property rights was a major problem for commerce and industry before 1688 , and that problem was alleviated by the political settlement of 1689 , then we should expect a big increase in the proportion of the economy devoted to commerce and industry in the years that immediately followed. The data from these social surveys do not tally with this. Furthermore, if the insecurity of property rights was a major impediment to economic growth before the Glorious Revolution, then how do we explain the substantial weight, growth, and economic importance of commerce and industry before 1688 ?

By this point the reader may be persuaded that the evidence undermines the claims of North and others concerning the economic consequences of the Glorious Revolution. But this would be a step too far. The remainder of this article shows how 1688 triggered a series of events that prepared the ground for the take-off after 1760.

We must examine events from the 1690 s to the 1750 s. We need to identify a chain of causation that connects the already-emergent bourgeoisie of 1688 with several later changes around the 1750s, including a marked quickening of economic growth, an increasing pace of reform of landed property rights, and a big increases in the pace of innovation. Such a causal chain would link 1688 to the Industrial Revolution that began around 1760.

\section{The financial and administrative revolutions}

In the 17th century, the Netherlands developed a relatively sophisticated system of public and private finance. The state was able to raise a steady supply of funds through taxation, on the basis of which the government was able to borrow. The Dutch developed a range of innovative institutional devices for investment in trade, industry, and infrastructure. Among these were public bonds, issued by governments on national, provincial, and municipal levels, and shares in publicly traded companies such as the Dutch East India Company. Financial markets, including the Amsterdam stock exchange, facilitated investment. Stock markets permitted smaller fractional shareholdings in mercantile and

14 As Lindert and Williamson (1982) pointed out, the three surveys differed in their methodologies and rigour. Hence, comparisons should be treated with caution, particularly when the reported differences are small. 
manufacturing enterprises. During the 17th century, about half of all ocean-going vessels worldwide were from the Netherlands. This tiny country dominated the international capital market, until successive political crises led to the collapse of the Dutch Republic in 1795 (Israel, 1989; de Vries and van der Woude, 1997).

Britain's Glorious Revolution of 1688 was in fact a Dutch-led invasion, albeit preceded by an invitation from a bishop and six members of the aristocracy. It had a religious motivation: James II was suspected of trying to restore Catholicism. The invading army of William of Orange involved 500 ships, 20,000 trained soldiers, and 20,000 mariners and support staff; it was similar in scale to the ill-fated Spanish Armada of a century earlier. William's army included English and Scottish exiles, plus mercenaries from Germany, Switzerland, Sweden, and elsewhere. It received widespread support from a predominantly Protestant population.

This invasion shifted English allegiances from France to the Netherlands and led to an influx of Dutch merchants and financiers, as well as artists and scientists (Jardine, 2008). Dutch businessmen brought knowledge of Dutch financial institutions and helped establish London as the world's leading financial centre (Dickson, 1967). Among Dutch innovations in public finance was the systematic dedication of revenues to the service and amortization of the public debt. Although Britain did not slavishly follow the Dutch, and it had made pre1688 institutional innovations of its own (Murphy, 2009), the ultimate impact of the Glorious Revolution on financial institutions was dramatic. Unsuccessful opponents of the 1694 formation of the Bank of England reportedly said that 'this project came from Holland and therefore would not hear of it, since we had too many Dutch things already' (Bank of England, 1970: 6). In the decades after 1688 , partly but not wholly as a result of the Dutch invasion, the institutional infrastructure of British finance was revolutionized.

North and Weingast (1989) argued that the diminished risks of debt default by the monarch lowered risk premiums and put downward pressure on rates of interest. By contrast, Clark $(1996,2007)$ argued that the evidence of falling interest rates is less clear. In any case, interest rates are determined by many factors, in addition to political risk, including the supply and demand for funds. These in turn are affected by institutionally backed opportunities for the collateralization of wealth and expectations of profit from investment. We may concur with Temin and Voth (2005: 325), and with Pincus and Robinson (2014: 205), that a narrow empirical focus on interest rates is 'fundamentally misguided' and 'a red herring'.

Epstein (2000: 211) argued that the constitutional restrictions on the power of the monarch in 1689 were less significant than England's 'belated catch up' with continental Europe's most developed financial systems: 'the result of the country's financial revolution rather than a revolution in political freedom and rights'. The new financial practices transplanted from the Netherlands were 
crucial (Bagehot, 1919; Carruthers, 1996; Dickson, 1967, Kindleberger, 1984, Neal, 1990, Powell, 1915; Roseveare, 1991; Wennerlind, 2011).

A boom in demand for stocks was underway in the 1690s, even before the Bank of England was formed (Murphy, 2009). Financed by London merchants, the Bank of England issued loans to the royal treasury at 8 per cent interest, the payments of which were in turn funded by taxes and custom duties. For the Bank of England these royal debts were its monetary assets, which in turn were buttressed by a renewed public faith in sovereign integrity. These assets became the basis of a further massive loan issue by the bank. The government borrowed widely, cementing together the interests of aristocrats, gentry, manufacturers, and merchants.

Market information became more available. By 1698, stock price quotes were regularly published in London (Morgan and Thomas, 1962). Also after 1688 'came a flurry of joint-stock company formations ... By 1695100 new companies had been formed with a capital of $£ 4.5$ million in all' (Kindleberger, 1984: 196). The Bank of England was followed by the establishment of several other London banks, about 25 in number by the 1720s and 50 in 1770 . Numerous banks began to appear in the provinces after 1750 (North and Weingast, 1989: 826).

Quinn's (2001: 613) study of the accounts of a prominent London banker showed how from 1680 to 1705 'the mechanics of private debt were transformed by the dual revolutions in England's systems of constitutional power and public finance. Bankers and their customers began to use the improved financial instruments of the government to facilitate private lending'.

In 1690, the prescient economist Nicholas Barbon helped to found the National Land Bank, which issued mortgages against real estate. By 1696, the Land Bank was so successful that it threatened to usurp the Bank of England. Also opposed by the Treasury and Parliament, this scheme eventually foundered. Clapham (1966: 33-34) puts this failure down to the underdeveloped state of the money and bond markets at the time. It took several decades to build up financial institutions under which available land could be readily mortgaged. In addition, as shown in Section 3 above, much land at that time could not yet be used as collateral. Further changes in the nature of land ownership were necessary, and these were slow in coming until the 1750s.

Much of the impetus for the heavy involvement of the state in the development of the British financial system in the 18th century was the need to finance wars abroad (Bowen, 1995: 5; Carruthers, 1996; Mann, 1986: 485-486). Because of its new international alliances and enemies, England was plunged into a long period of war, requiring major reform of its fiscal and administrative arrangements. The Nine Years' War (1688-1697) was quickly followed by the long War of Spanish Succession (1701-1713). The overthrow of the Stuarts in 1688 led within Britain to the Jacobite Rebellions of 1715 and 1745 . There was the War of the Quadruple Alliance (1718-1720), the Anglo-Spanish 
War (1727-1729), the War of the Austrian Succession (1740-1748), and the global Seven Years' War of (1756-1763). Britain was involved in war, with at least one other major power, in 45 of the 76 years from 1688 to 1763 inclusive.

Finance and war were intimately connected. As Carruthers (1996: 8) noted, in 1672, although there were trading in stocks, there was no organized stock market in London, and 'England was a weak nation-state and a second-rate military power. In 1712, only 40 years later, the shares of many joint-stock companies were traded on an active and highly organized capital market that had emerged in London. Furthermore, Great Britain had become one of the major military powers in Europe and had successfully checked French expansion'.

Contrary to the claim of North and Weingast (1989) that the political settlement of 1689 made government more stable, Pincus and Robinson (2014: 199) wrote: 'Far from making government more predictable, the Revolution of 1688 instantiated one of the most intensely polarized and unstable periods in English and British history'. The litany of war and revolt from 1688 to 1763 underlines this.

Of course, there were many wars before 1688 . For example, in the years after the Restoration, there were the Second (1665-1667) and Third (16721674) Anglo-Dutch Wars. But the sovereign often had difficulty raising money to finance these ventures. What changed in 1689 was the practical accord between the sovereign and Parliament, which ultimately locked them together in common cause, especially when dealing with enemies abroad, despite no shortage of fractious internal disputes in those difficult times. 1689 secured the compliance of both King and commons in meeting the needs of war. North and Weingast (1989) were right about the importance of the Glorious Revolution, but for the wrong reasons. It had little immediate effect on the security of property rights.

By accident or design, some measures indirectly made regular parliaments more likely, especially in the context of war. The 1689 Declaration of Right required that no standing army may be maintained during peacetime without the consent of Parliament. In the same year, the Mutiny Act was passed to deal with some rebellious Scottish troops who had remained loyal to James II. This Act allowed the sovereign to maintain a standing army in war or peace, for one year, but no longer. Consequently, if the country were to be kept on a war footing, parliament had to meet annually and renew the Mutiny Act (Winthrop, 1920: 19-20). A new Mutiny Act was passed each year until 1879. In addition, the financial settlement of 1690 put time-limits on funds for the monarch, which had previously been granted for life (Roberts, 1977). Again this reinforced the sovereign's dependence of regular parliaments.

Parliament became more able to put the king on a shorter financial leash, to control government debt, and to control its executive (Cox, 2012, 2016). Military and financial needs also helped Parliament keep the monarch under control. 
The state continued to play an important role in stimulating corporate activity overseas. The Crown organized groups of creditors into companies, including the New East India Company (1698), the United East India Company (1708), and the South Sea Company (1708). The South Sea Bubble of 1720 led to a severe crash, but the financial system as a whole recovered.

This period saw expansion of the British Empire. Before 1688, England had major colonies in North America, the Caribbean, and West Africa. By 1763, Britain had gained more territory in India and North America and it had established a strategic Mediterranean base in Gibraltar. The growth of slavery was another part of Britain's increased trading activity from the 1690s to the 1760s. More broadly, as Patrick O'Brien (2006: 14) pointed out: 'Already by the close of the Seven Years' War, something like half of the nation's workforce (delinked from agriculture) depended directly and indirectly on markets overseas for its livelihood'.

From 1687 to 1703 , the number of workers employed in naval yards more than quadrupled. Daniel Defoe remarked at the time that 'in some respects the navy is largest industry in the country' (Hill, 1961: 230). More people were required to administer the growing war machine and to raise taxes to finance it.

The needs of war and the combined pressures of global and domestic commerce were major forces behind the development and reform of financial institutions and state administration (O'Brien, 2011). The Glorious Revolution and subsequent international conflicts led to major transformations of the state apparatus, including the Act of Union with Scotland in 1707. As Roseveare (1991: 4) pointed out, accompanying the political and fiscal changes after 1688 there was 'an administrative revolution - or, at least, a striking growth in the power and effectiveness of the state which manifested itself not merely in war but in the subtler tasks of peace'.

Figure 2 shows the growth of the number of full-time employees involved in the fiscal bureaucracy, including those in customs, excise, the post office, and the Treasury. It shows a remarkable rise from 1690 to the 1720 s, when the bureaucracy more than doubled in size.

The state administration established a stronger fiscal base and empowered a growth in tax revenues, particularly to finance wars. The settlement of 1689 strengthened the political consensus, creating the foundation of an effective fiscal state (Roseveare, 1991). In 1692, Parliament introduced a national land tax. A window tax was introduced in 1696. But the major part of state revenue was through customs and excise charges, which increased with the growth of Britain's power and trade abroad (Mathias, 1983: 428).

Figure 3 shows the total tax revenue as a proportion of national income from 1670 to 1810 . There is a marked rise from 1680 to 1690 , and thereafter to 1700 . Consequently, impelled by the outbreak of war in 1688, and as a result of the settlement of 1689 , the government was able to ramp up tax revenues, more than doubling the tax-take as a percentage of national income. Ironically, the most 
Figure 2. Full-time employees in the state fiscal bureaucracy, 1690-1783.

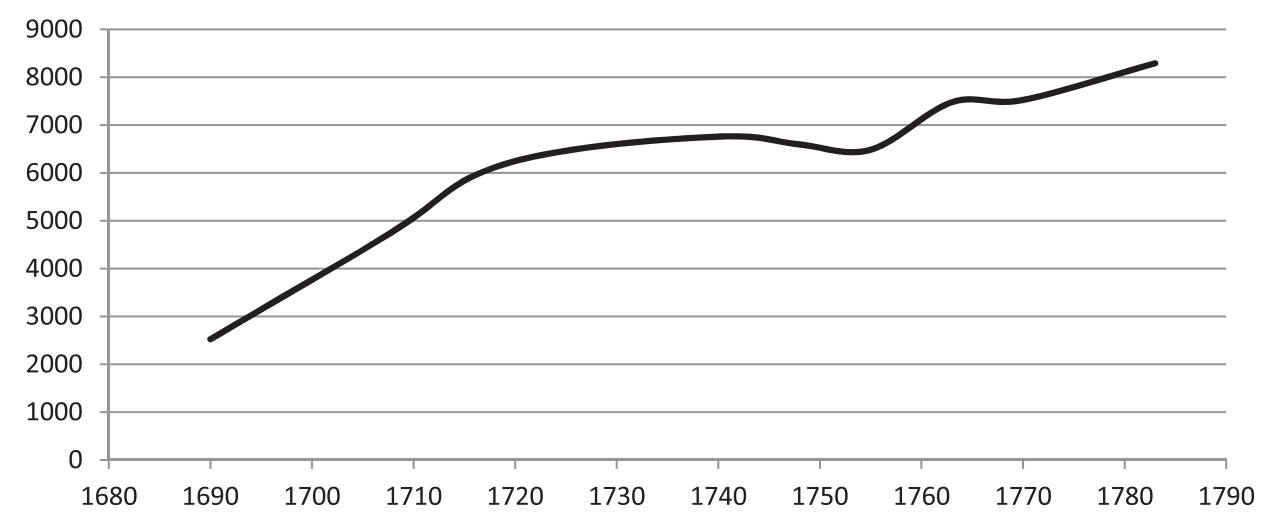

Source: Data from Brewer (1988: 66).

Figure 3. Total tax revenue as a proportion of national income, 1670-1810.

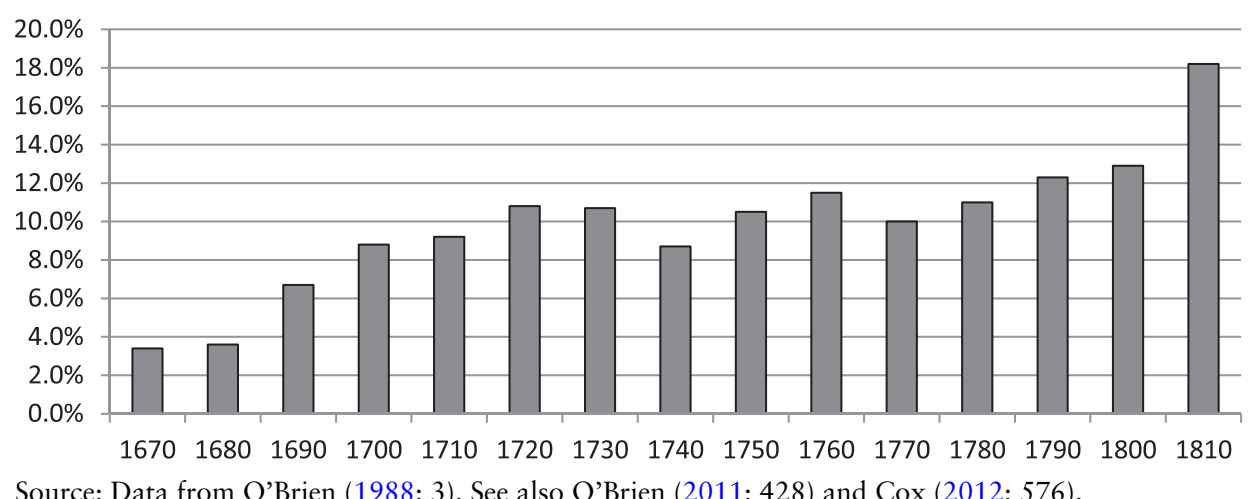

obvious and immediate effects of 1688 were not a growth in free enterprise, but a considerable expansion in state bureaucracy and taxation.

The Financial Revolution was a protracted affair, lasting decades. It involved several legislative steps, including changes to laws concerning usury and the sale of debt, and the development of new organizational structures and business habits. The growing use of debt led to instability as well as growth (as exhibited in the South Sea Bubble of 1720) and Temin and Voth (2005) have provided evidence to argue that wartime government borrowing crowded out private lending. Nevertheless, the overall effect of the Financial Revolution was positive. Above all, it enlarged possibilities for borrowing and investment, by establishing a modern banking system. These institutional changes bore fruit in the Industrial Revolution.

Addressing the evolution of finance in Italy, the Netherlands and Britain, Ingham (2008: 70) concluded that 'the capitalist monetary system developed 
from the integration of private networks of mercantile trade credit-money with public currency - that is, state money'. For Ingham (2008: 74) and others, crucial to this system was the role of debt: 'Capitalism is distinctive in that it contains a social mechanism by which privately contracted debtor-creditor relations ... are routinely monetized'.

Vital to the development of a modern banking system was the emergence of institutions making debt itself saleable or 'negotiable'. A promise to pay could then be sold to another, who would then take on the legal obligation of payment. A key problem is effective legal enforceability. For general negotiability, the transfer of obligations also had to be recognized and enforced by the legal system. Contracts ordinarily involve legal obligations to deliver goods or services in exchange for money. Exchanges of promissory notes involve instead the purchase of a promise, and originally this was not recognized as a valid contract in law: the selling of debt was not sanctioned by legal recognition of the transfer of the obligation to its purchaser. Major legislative changes were necessary to make this possible.

In the 17th century, commercial cases shifted from the law merchant courts to common law courts (Baker, 1979; Berman, 1983). But the 'blundering attempts' by common law courts (Beutel, 1938: 840) to deal with the negotiability of debt led businessmen to press Parliament for robust legislation. In a way this underlines the importance of the 1689 settlement, which enlarged the effective legislative capacity of Parliament. In 1704, during the reign of William's successor Queen Anne, Parliament passed 'An Act for giving like Remedy upon Promissory Notes, as is now used upon Bills of Exchange, and for the better Payment of Inland Bills of Exchange' Significant further legislation, including another Act as late as 1758 , was required to consolidate negotiability (Beutel, 1938; Lawrence, 2002). Once negotiability was established, the capitalist genie was out of the bottle. As MacLeod (1872: 481) wrote:

If we were asked - Who made the discovery which has most deeply affected the fortunes of the human race? We think, after full consideration, we might safely answer - The man who first discovered that a Debt is a Saleable Commodity. ${ }^{15}$

The use of this 'discovery' required firm legal foundations and consolidation through more than one Act of Parliament. But eventually, through these means, the emerging capitalist financial system empowered economic development on a massive scale.

Capitalist finance involves a complex web of contractual obligations. Commercial banks since the 14th century operated increasingly by keeping only

15 MacLeod (1858: 476-478) coined the term ‘Gresham's Law'. Mitchell Innes (1914: 9) credited him as the originator of the state theory of money. Commons (1934:394) described him as 'the first lawyereconomist'. Schumpeter (1954: 718) judged him the only contemporary of Marx to make a systematic advance towards a credit theory of money. 
a fraction of their deposits in reserve as cash or gold. Fractional-reserve banking has a cumulative effect on money creation by commercial banks as it expands the money supply beyond the scale of the deposits alone. Any debt is funded by current assets, or by claims owed by a third party. The purchaser of debt receives the right to an asset that itself can be used as collateral to borrow (Veblen, 1904: 113, 149). Credit money thus feeds on itself: commercial bank money is created endogenously (Moore, 1988; Wray, 2012). As if in defiance of the conservation laws of physics, banks can thus create more money 'out of nothing' (Schumpeter, 1934: 73).

But this depends on a legal structure of enforceability, a fractional reserve system backed by private and state assurances, and sufficient confidence that debt can be redeemed. In Britain, once legal institutions supporting collateralizable property, credit money, and the sale of debt were in place, a new dynamic was unleashed.

The argument in brief is this. The evolution of the financial system in the first half of the 18th century facilitated more and more industrial and infrastructural projects based on large-scale borrowing. They triggered another process of cumulative causation and positive feedback, which became evident by the 1750s. As the profitability of larger-scale investments was demonstrated, wealthy landowners and other investors were enticed by further commercial ventures. Growing opportunities for profit eroded longstanding, sentimental, family commitments to their estates. This impelled the removal of entails and strict settlements, so that land could be used as collateral for loans. Hence, the major capitalist reforms to property rights in land followed rather than preceded the Financial Revolution.

Consequently, institutional changes in the 18th century increased the stock of property that was usable as collateral, creating the opportunity for increased loans. The growth of incentives and opportunities for borrowing, alongside the development of post-1694 arrangements in a debt-based monetary system based on negotiable paper, enlarged the market for debt, fuelling further speculation and investment. A modern financial system developed, which rested on the pillars of collateralizable property, negotiable debt, global trade, and state power.

\section{Conclusion: from critique to reconstruction}

The Glorious Revolution made no laws concerning property and made few edicts the role of Parliament. It did not increase the security of property rights, and it did not lead to an immediate acceleration in the pace of economic growth or of a growth in the economic weight of the bourgeoisie. But it did have two major portentous effects.

First, as evidenced by the nature and pace of legislation after 1689, there was a shift in the de facto balance of power between the sovereign and Parliament. As North and others emphasized, this countervailing power placed important 
checks on the powers of the monarch. Nevertheless, this shift is insufficient to account for the reforms to property and finance that were necessary to sustain a rising capitalist economy. The power and motivation of a rising bourgeois class were necessary to overcome the vested interests in existing, semi-feudal landed property rights. This did not happen until long after 1688 .

Second, 1688 meant a major shift in foreign alliances and prompted a number of major wars, up to the Seven Years' War of 1755-1763. Facilitated by the enhanced de facto role of Parliament, international conflict forced reform upon the British state, and required it to raise funds to finance war. The Financial and Administrative Revolutions of the early 18th century were the most immediate outcomes of 1688 . Hence it was the financial and military needs of the state, more than the rising bourgeoisie, which provided the main impetus for change from 1688 to 1750 .

But institutional changes, particularly in the spheres of law and politics, combined with the demands of war upon industrial production, eventually facilitated a rise in the weight and influence of the industrial and commercial classes, which in turn benefitted from expanding British trade and Empire. These socio-economic results were discernible by 1760 .

As the industrial take-off gathered pace after 1760, it increased the pressure to reform property rights in land, so that it could be used as collateral for industrial and commercial investments. New pecuniary opportunities overcame the resistance to reform by conservative landowners. While much industrial investment came out of existing profits, such sources were sometimes inadequate or unreliable. Some firms issued shares. Other finance for investment in industrial ventures was obtained via relatives, friends, intermediaries or banks, sometimes requiring land or other collateral to secure the loan (Crouzet, 1990, ch. 5; Heaton, 1937; King and Timmins, 2001: 114-120; Mathias, 1983: 130-136).

Writing of the early phase of the Industrial Revolution, Ashton (1955: 26) concluded: 'It is true that self-financing was a marked feature of the period, but it would be an error to consider it as universal or to think of the markets for capital as circumscribed'. As Mathias (1983: 135) noted: 'Freehold property remained the best security extant in 18th-century England, and the mortgage market was one of the most efficiently organized sides of the capital market'.

For example, the firm of Boulton and Watt - founded in 1775 and famous for the manufacture of steam engines - took out mortgages on land and other assets to secure loans for their budding enterprise (Roll, 1930: 105-107). Similarly, around that time, mortgages were sometimes used to help finance canal construction, alongside the issue of shares (Ward, 1974: 35, 116). ${ }^{16}$

16 A more comprehensive account of the extent of the use of collateral to finance industrial projects in the late eighteenth and early nineteenth centuries is a matter for further research. Insufficient attention has been devoted to this topic, because of the inadequate recognition of the importance of collateralization and because of the widespread conflation by economists of 'capital' as things (such as machinery) with 
The account here puts the growth of finance at the centre in the explanation of the rise of capitalism. Neither the establishment of secure property rights (North) nor the rise of a capitalist class employing waged labour (Marx) accurately characterize the period from 1688 to 1750 . Although secure property rights, trade, and wage labour may be taken as necessary features of capitalism, they are insufficient to define that system. At the core of capitalism - as it emerged in the 18th century - is a set of financial institutions based on collateralizable property and credit creation. These institutions and the monetary system are typically buttressed by the state (Hodgson, 2015a; Ingham 2008).

As Schumpeter (1939: 223) pointed out, 'capitalism is that form of private property economy in which innovations are carried out by means of borrowed money, which in general ... implies credit creation'. Money is borrowed on the basis of collateral. Yet this aspect of property is neglected in much of the 'economics of property rights', which concentrates instead on property in terms of control. Schumpeter (1954: 78) also emphasized 'the importance of the financial complement of capitalist production and trade'. Hence, 'the development of the law and the practice of negotiable paper and of "created" deposits afford perhaps the best indication we have for dating the rise of capitalism'.

This article has located key developments in financial institutions in the opening decades of the 18th century. These institutional changes, tied up with reformed financial and administrative functions for the state, provide the missing causal links between the Glorious Revolution of 1688, the rise of capitalist financial institutions, and the beginnings of the Industrial Revolution around 1760 .

If this analysis applies to the development of capitalism in countries beyond Britain, then it would suggest that the building of a state administration, which can sustain a modern monetary system and secure the use of private property as collateral, is an important precondition of rapid economic growth. Hence a stress on the 'security of property rights' would be insufficient in developing countries. The nature of property, and its connection with finance and politics, has to be better understood.

\section{References}

Acemoglu, D., S. Johnson and J. A. Robinson (2005a), 'Institutions as a Fundamental Cause of Long-Run Growth', in Philippe Aghion and Steven N. Durlauf (eds.), Handbook of Economic Growth: Volume 1A, North Holland: Elsevier, pp. 385-472.

Acemoglu, D., S. Johnson and J. A. Robinson (2005b), 'The Rise of Europe: Atlantic Trade, Institutional Change and Economic Growth', American Economic Review, 95(3): 546579 . 
Acemoglu, D. and J. A. Robinson (2012), Why Nations Fail: The Origins of Power, Prosperity, and Poverty, New York: Random House and London: Profile.

Alchian, A. A. (1965), 'Some Economics of Property Rights', Il Politico, 30, pp. 816-829. Reprinted in A. A. Alchian (1977), Economic Forces at Work, Indianapolis: Liberty Press, pp. 127-149.

Allen, D. W. (2012), The Institutional Revolution: Measurement and the Economic Emergence of the Modern World, Chicago: University of Chicago Press.

Allen, R. C. (2009), The British Industrial Revolution in Global Perspective, Cambridge and New York: Cambridge University Press.

Angeles, L. (2011), 'Institutions, Property Rights, and Economic Development in Historical Perspective', Kyklos, 64(2): 157-77.

Arruñada, B. (2016), 'Coase and the Departure from Property', in M. Claude and B. Elodie (eds.), The Elgar Companion to Ronald H. Coase, Cheltenham, UK and Northampton, MA: Edward Elgar, pp. 305-319.

Ashton, T. S. (1955), An Economic History of England: The Eighteenth Century, London: Methuen.

Bagehot, W. (1919), Lombard Street: A Description of the Money Market, (1st edn 1873), London: Murray.

Baker, J. H. (1979), 'The Law Merchant and the Common Law before 1700', Cambridge Law Journal, 38(2): 295-322.

Bank of England (1970), The Bank of England: History and Functions, Debden: Gordon Chalmers Fortin.

Barzel, Y. (1989), Economic Analysis of Property Rights, Cambridge: Cambridge University Press.

Berman, H. J. (1983), Law and Revolution: The Formation of the Western Legal Tradition, Cambridge, MA: Harvard University Press.

Berman, H. J. (2003), Law and Revolution II: The Impact of the Protestant Reformations on the Western Legal Tradition, Cambridge, MA: Harvard University Press.

Beutel, F. K. (1938), 'The Development of Negotiable Instruments in Early English Law', Harvard Law Review, 51(5): 813-845.

Bogart, D. (2005), 'Did Turnpike Trusts Increase Transportation Investment in Eighteenth Century England?', Journal of Economic History, 65(2): 439-68.

Bogart, D. (2011), 'Did the Glorious Revolution Contribute to the Transport Revolution? Evidence from Investment in Roads and Rivers', Economic History Review, 64(4): 1073-1112.

Bogart, D. and G. Richardson (2011), 'Property Rights and Parliament in Industrializing Britain', Journal of Law and Economics, 54(2): 241-274.

Bowen, H. V. (1995), 'The Bank of England During the Long Eighteenth Century: 16941815,' in Richard Roberts and David Kynaston (eds.), The Bank of England, Oxford and New York: Oxford University Press, pp. 1-18.

Braudel, F. (1984), Civilization and Capitalism, 15th-18th Century, Vol. 3, The Perspective of the World, London: Collins.

Brewer, J. (1988), The Sinews of Power: War, Money and the English State, 1688-1783, New York: Knopf.

Broadberry, S. N., Bruce M. S. Campbell, A. Klein, M. Overton and Bas van Leeuwen (2015), British Economic Growth 1270-1870: An Output-Based Approach, Cambridge and New York: Cambridge University Press. 
Carruthers, B. G. (1996), City of Capital: Politics and Markets in the English Financial Revolution, Princeton, NJ and Chichester, UK: Princeton University Press.

Castor, H. (2006), Blood and Roses: One Family's Struggle and Triumph during the Tumultuous Wars of the Roses, New York: Harper Collins.

Cipolla, C. M. (1965), Guns, Sails and Empires: Technological Innovation and the Early Phases of European Expansion, 1400-1700, New York: Pantheon.

Clapham, J.H. (1966), The Bank of England: A History. Volume One, 1694-1797, Cambridge: Cambridge University Press.

Clark, G. (1996), 'The Political Foundations of Modern Economic Growth: England, 15401800', Journal of Interdisciplinary History, 26(4): 563-588.

Clark, G. (2007), A Farewell to Alms: A Brief Economic History of the World, Princeton: Princeton University Press.

Cole, D. H. (2015), “"Economic Property Rights” as "Nonsense upon Stilts”: A Comment on Hodgon's Article', Journal of Institutional Economics, 11(4): 725-730.

Cole, D. H. and P. Z. Grossman (2002), 'The Meaning of Property Rights: Law versus Economics?', Land Economics, 78(3): 317-330.

Commons, J. R. (1934), Institutional Economics - Its Place in Political Economy, New York: Macmillan.

Cox, G. W. (2012), 'Was the Glorious Revolution a Constitutional Watershed', Journal of Economic History, 72(3): 567-600.

Cox, G. W. (2016), Marketing Sovereign Promises: Monopoly Brokerage and the Growth of the English State, Cambridge and New York: Cambridge University Press.

Crouzet, F. (1990), Britain Ascendant: Comparative Studies in Franco-British Economic History, Cambridge and New York: Cambridge University Press.

De Soto, H. (2000), The Mystery of Capital: Why Capitalism Triumphs in the West and Fails Everywhere Else, New York: Basic Books.

Deakin, S., Gindis, D., G. M. Hodgson, Kainan Huang and K. Pistor (2016), 'Legal Institutionalism: Capitalism and the Constitutive Role of Law', Journal of Comparative Economics, published online.

Dickson, P. G. M. (1967), The Financial Revolution in England: A Study in the Development of Public Credit, 1688-1756, London: Macmillan.

Dutton, H. I. (1984), The Patent System and Inventive Activity during the Industrial Revolution, 1750-1852, Manchester: Manchester University Press.

Eltis, D. (2001), 'The Volume and Structure of the Transatlantic Slave Trade: A Reassessment', William and Mary Quarterly, 58(1): 17-46.

English, B. and John Saville (1983), Strict Settlement: A Guide for Historians, Hull: University of Hull Press.

Epstein, S. R. (2000), Freedom and Growth: The Rise of States and Markets in Europe, 1300-1750, London and New York: Routledge.

Eric, R. (1930), An Early Experiment in Industrial Organisation: Being a History of the Firm of Boulton and Watt 1775-1805, Abingdon: Frank Cass.

Heaton, H. (1937), 'Financing the Industrial Revolution', Bulletin of the Business Historical Society, 11(1), 1-10.

Heinsohn, G. and O. Steiger (2013), Ownership Economics: On the Foundations of Interest, Money, Markets, Business Cycles and Economic Development, Frank Decker (ed.), London and New York: Routledge.

Heller, M. A. (2008), The Gridlock Economy: How Too Much Ownership Wrecks Markets, Stops Innovation, and Costs Lives, New York: Basic Books. 
Hill, C. (1961), The Century of Revolution 1603-1714, London: Van Nostrand Reinhold.

Hodgson, G. M. (2014), 'What is Capital? Economists and Sociologists have Changed its Meaning - Should it be Changed Back?', Cambridge Journal of Economics, 38(5): 1063-1086.

Hodgson, G. M. (2015a), Conceptualizing Capitalism: Institutions, Evolution, Future, Chicago: University of Chicago Press.

Hodgson, G. M. (2015b), 'Much of the "Economics of Property Rights” Devalues Property and Legal Rights', Journal of Institutional Economics, 11(4): 683-709.

Hodgson, G. M. (2015c), 'What Humpty Dumpty Might Have Said About Property Rights - And the Need to Put Them Back Together Again: A Response to Critics', Journal of Institutional Economics, 11(4): 731-747.

Honoré, A. M. (1961), 'Ownership', in Anthony G. Guest (ed.) Oxford Essays in Jurisprudence, Oxford: Oxford University Press, pp. 107-147. Reprinted in the Journal of Institutional Economics, 9(2): 2013, 227-255.

Hoppit, J. (2011), 'Compulsion, Compensation and Property Rights in Britain, 1688-1833', Past and Present, 210(1): 93-128.

Ingham, G. (2004), The Nature of Money, Cambridge: Polity Press.

Ingham, G. (2008), Capitalism, Cambridge: Polity Press.

Israel, J. I. (1989), Dutch Primacy in World Trade 1585-1740, Oxford and New York: Oxford University Press.

Jardine, L. (2008), Going Dutch: How England Plundered Holland's Glory, London: Harper.

Jones, J. R. (1992), Liberty Secured? Britain Before and After 1688, Stanford, CA: Stanford University Press.

Keynes, J. M. (1930), A Treatise on Money, Vol. 1: The Pure Theory of Money, Vol. 2: The Applied Theory of Money, London: Macmillan.

Kindleberger, C. P. (1984), A Financial History of Western Europe, London: George Allen and Unwin.

King, S. and G. Timmins (2001), Making Sense of the Industrial Revolution: English Economy and Society 1700-1850, Manchester: Manchester University Press.

Lawrence, W. H. (2002), Understanding Negotiable Instruments and Payment Systems, Newark, NJ: Matthew Bender.

Lindert, P. H. and Williamson, J. G. (1982), 'Revising England's Social Tables, 1688-1812', Explorations in Economic History, 19(4): 385-408.

MacLeod, C. (2002), Inventing the Industrial Revolution: The English Patent System, 16601800, Cambridge and New York: Cambridge University Press.

MacLeod, H. D. (1858), Elements of Political Economy, London: Longmans Green.

MacLeod, H. D. (1872), The Principles of Economic Philosophy, 2nd edn., London: Longmans Green.

Maddison, A. (2007), Contours of the World Economy, 1-2030 AD: Essays in MacroEconomic History, Oxford and New York: Oxford University Press.

Mann, M. (1986), The Sources of Social Power, Volume 1: A History of Power from the Beginning to A.D. 1760, Cambridge: Cambridge University Press.

Marx, K. (1976), Capital, vol. 1, Harmondsworth: Pelican. Translated from the fourth German edition of 1890 .

Mathias, P. (1983), The First Industrial Nation: An Economic History of Britain 1700-1914, 2nd edn London and New York: Routledge.

McCloskey, D. N. (2010), Bourgeois Dignity: Why Economics Can't Explain the Modern World, Chicago: University of Chicago Press. 
McCloskey, D. N. (2016), 'Max U vs. Humanomics: A Critique of Neo-Institutionalism', Journal of Institutional Economics, 12(1): 1-27.

Mitchell Innes, Alfred (1914), 'The Credit Theory of Money', The Banking Law Journal, 31, 151-168.

Moore, Basil J. (1988), Horizontalists and Verticalists: The Macroeconomics of Credit Money, Cambridge: Cambridge University Press.

Morgan, E. Victor and W. A. Thomas (1962), The Stock Exchange, Its History and Functions, London: Elek Books.

Morrill, J. (1992), 'The Sensible Revolution', in Jonathan I. Israel (ed.), The Anglo-Dutch Moment: Essays on the Glorious Revolution and its World Impact, Cambridge and New York: Cambridge University Press, pp. 73-104.

Murphy, A. L. (2009), The Origins of English Financial Markets: Investment and Speculation before the South Sea Bubble, Cambridge and New York: Cambridge University Press.

Murphy, A. L. (2013), 'Demanding “Credible Commitment”: Public Reactions to the Failures of the Early Financial Revolution', Economic History Review, 66(1): 178-197.

Neal, L. (1990), The Rise of Financial Capitalism: International Capital Markets in the Age of Reason, Cambridge and New York: Cambridge University Press.

Nenner, H. (ed.) (1997), Politics and Political Imagination in Later Stuart Britain, Rochester, NY: University of Rochester Press.

North, D. C. (1981), Structure and Change in Economic History, New York: Norton.

North, D. C. (1994), 'Economic Performance through Time', American Economic Review, 84(3): 359-367.

North, D. C., J. J. Wallis and B. R. Weingast (2009), Violence and Social Orders: A Conceptual Framework for Interpreting Recorded Human History, Cambridge: Cambridge University Press.

North, D. C. and B. R. Weingast (1989), 'Constitutions and Commitment: The Evolution of Institutions Governing Public Choice in Seventeenth-Century England', Journal of Economic History, 49(4): 803-832.

O’Brien, P. K. (1988), 'The Political Economy of British Taxation, 1660-1815', Economic History Review, New Series, 41(1): 1-32.

O'Brien, P. K. (2006), 'Provincializing the First Industrial Revolution', Working Paper 17/06, Global Economic History Network (GEHN), London School of Economics. http://eprints.lse.ac.uk/22474/1/wp17.pdf (retrieved 20 February 2016.)

O'Brien, P. K. (2011). 'The Nature and Historical Evolution of an Exceptional Fiscal State and its Possible Significance for the Precocious Commercialization and Industrialization of the British Economy from Cromwell to Nelson', Economic History Review, 64(2): $408-446$.

O'Gorman, F. (1997), The Long Eighteenth Century: British Political and Social History 1688-1832, New York: Arnold Press.

Ogilvie, S. and A. W. Carus (2014), 'Institutions and Economic Growth in Historical Perspective', in P. Aghion and S. Durlauf (eds.), Handbook of Economic Growth, vol. 2A, Amsterdam: Elsevier, pp. 403-513.

Olson, M., Jr. (2000), Power and Prosperity: Outgrowing Communist and Capitalist Dictatorships, New York: Basic Books.

Olson, Mancur Jr. (1993), 'Dictatorship, Democracy, and Development', American Political Science Review, 87(3): 567-576.

Ostrom, E. (1990), Governing the Commons: The Evolution of Institutions for Collective Action, Cambridge: Cambridge University Press. 
Phillips, J. A. and C. Wetherell (1995), 'The Great Reform Act of 1832 and the Political Modernization of England', American Historical Review, 100(2): 411-436.

Pincus, S. C. A. (2009), 1688: The First Modern Revolution (New Haven: Yale University Press).

Pincus, S. C. A. and J. A. Robinson (2014), 'What Really Happened During the Glorious Revolution?', in Galiani Sebastian and Sened Itai (eds.), Institutions, Property Rights, and Economic Growth: The Legacy of Douglass North, Cambridge and New York: Cambridge University Press, pp. 192-222.

Powell, E. T. (1915), The Evolution of the Money Market (1385-1915): An Historical and Analytical Study of the Rise and Development of Finance as a Centralised, Co-ordinated Force, London: Financial Press.

Quinn, S. (2001), 'The Glorious Revolution's Effect on English Private Finance: A Microhistory 1680-1705', Journal of Economic History, 61(3): 593-615.

Roberts, C. (1977), 'The Constitutional Significance of the Financial Settlement of 1690', The Historical Journal, 20(1): 59-76.

Roseveare, H. G. (1991), The Financial Revolution, 1660-1760, Harlow: Longman.

Schumpeter, J. A. (1934), The Theory of Economic Development: An Inquiry into Profits, Capital, Credit, Interest, and the Business Cycle, Cambridge, MA: Harvard University Press.

Schumpeter, J. A. (1939), Business Cycles: A Theoretical Statistical and Historical Analysis of the Capitalist Process, 2 vols., New York: McGraw-Hill.

Schumpeter, J. A. (1954), History of Economic Analysis, Oxford and New York: Oxford University Press.

Scott, J. (1991), Algernon Sydney and the Restoration Crisis, 1677-1683, Cambridge and New York: Cambridge University Press.

Steiger, O. (ed.) (2008), Property Economics: Property Rights, Creditor's Money and the Foundations of the Economy, Marburg: Metropolis.

Sullivan, R. J. (1989), 'England's “Age of Invention”: the Acceleration of Patents and of Patentable Invention during the Industrial Revolution', Explorations in Economic History, 26(4): 424-452.

Sussman, N. and Y. Yafeh (2006), 'Institutional Reforms, Financial Development and Sovereign Debt: Britain 1690-1790', Journal of Economic History, 66(4): 906-935.

Temin, P. and H.-J. Voth (2005), 'Credit Rationing and Crowding Out During the Industrial Revolution: Evidence from Hoare's Bank, 1702-1862', Explorations in Economic History, 42: 325-348.

Trevor-Roper, H. (1992), Counter-Reformation to Glorious Revolution, Chicago: University of Chicago Press.

Turner, M. (1986), 'English Open Fields and Enclosures: Retardation or Productivity Improvements', Journal of Economic History, 46(3): 669-692.

Veblen, T. B. (1904), The Theory of Business Enterprise, New York: Charles Scribners.

Veblen, T. B. (1908), 'Professor Clark's Economics', Quarterly Journal of Economics, 22(2): 147-195.

Veitch, J. M. (1986), 'Repudiations and Confiscations by the Medieval State', Journal of Economic History, 46(1): 31-36.

de Vries, Jan and Ad van der Woude (1997), The First Modern Economy. Success, Failure, and Perseverance of the Dutch Economy, 1500-1815, Cambridge and New York: Cambridge University Press. 
Ward, J. R. (1974), The Finance of Canal Building in Eighteenth-Century England, Oxford: Oxford University Press.

Wennerlind, C. (2011), Casualties of Credit: The English Financial Revolution 1620-1720, Cambridge, MA: Harvard University Press.

Western, J. R. (1972), Monarchy and Revolution: The English State in the 1680s, London: Blandford.

Winthrop, W. (1920), Military Law and Precedents, 2nd edn, Washington: Government Printing Office.

Wray, L. R. (2012), Modern Money Theory: A Primer on Macroeconomics for Sovereign Monetary Systems, London and New York: Palgrave Macmillan. 